\title{
UNIA EUROPEJSKA WOBEC PROCESU ZARZĄDZANIA INTERNETEM
}

\author{
Łukasz Morawski \\ Instytut Studiów Politycznych Polskiej Akademii Nauk \\ ul. Polna 18/20, 00-625 Warszawa, \\ email: 1morawski84@gmail.com
}

\begin{abstract}
Streszczenie: Internet w stosunkowo krótkim czasie stał się jednym z głównych i najistotniejszych mediów naszych czasów. Wzrastająca liczba jego użytkowników, jak również wzrost jego roli i znaczenia w niemalże każdym aspekcie życia społeczno-gospodarczego spowodowały w ostatnich latach nasilenie się dyskusji na temat przyszłości internetu i sposobu w jaki powinien być zarządzany. Internet od samego początku rozwijał się oddolnie bez centralnego ośrodka decyzyjnego. Na świecie funkcjonuje wiele organizacji działających na poziomie lokalnym, regionalnym i globalnym, które skupiają się na różnych aspektach jego działania i rozwoju. Proces nazywany „zarządzanie Internetem” (Internet Governance), to proces, w którym rządy, przedsiębiorstwa z branży technologii informacyjnych i komunikacyjnych oraz społeczeństwo obywatelskie wspólnie wypracowują standardy, wartości, normy i decyzje, które kształtują sposób, w jaki użytkowana jest sieć. Niniejszy artykuł podejmuje próbę wyjaśnienia tego zjawiska, przedstawia genezę sporu pomiędzy zwolennikami wielostronnego modelu zarządzania internetem oraz państwami postulującymi wzmocnienie roli rządów w tym procesie oraz prezentuje stanowisko Unii Europejskiej, która może w tej dyskusji odegrać kluczową rolę stając się mediatorem $\mathrm{w}$ debacie o przyszłym modelu zarządzania internetem.
\end{abstract}

Słowa kluczowe: zarządzanie Internetem, Unia Europejska, ICANN, internet, społeczeństwo informacyjne.

\section{WSTĘP}

Internet w stosunkowo krótkim czasie stał się jednym z głównych i najistotniejszych mediów naszych czasów. ${ }^{1}$ Swoim zasięgiem obejmuje już prawie 3 mld użytkowników na całym świecie ${ }^{2}$ i w znaczący sposób oddziałuje na

1 O historii internetu zob. J. Abbate, Inventing the Internet, Cambridge1999.

2 ITU releases 2014 ICT figures. Mobile-broadband penetration approaching 32 per cent. Three billion Internet users by end of this year, http://www.itu.int/net/pressoffice/press_releases/2014/23.aspx\#.VPmYK3yG9XE (dostęp z 6.02.2015). 
prawie wszystkie aspekty życia społeczno-gospodarczego. Wzrastająca liczba użytkowników, jak również wzrost jego roli i znaczenia w wymiarze społeczno-kulturowym, gospodarczym, bezpieczeństwa, czy praw człowieka ${ }^{3}$ spowodowały w ostatnich latach nasilenie się dyskusji na temat przyszłości internetu i sposobu w jaki powinien być zarządzany.

Od samego początku internet rozwijał się oddolnie bez centralnego ośrodka decyzyjnego. Na świecie funkcjonuje wiele organizacji na poziomie lokalnym, regionalnym i globalnym, które skupiają się na różnych aspektach działania i rozwoju internetu. Proces nazywany ,zarządzaniem Internetem” (Internet Governance), to proces, w którym rządy, przedsiębiorstwa z branży technologii informacyjnych i komunikacyjnych oraz społeczeństwo obywatelskie wspólnie wypracowują standardy, wartości, normy i decyzje, które kształtują sposób, w jaki użytkowana jest sieć.

Na poziomie globalnym zaobserwować można ścieranie się dwóch tendencji: $\mathrm{z}$ jednej strony widoczne jest poszanowanie $\mathrm{i}$ ochrona wielostronnego modelu zarządzania internetem, a z drugiej tendencja do zwiększania zakresu kontroli i wpływu rządów na Internet. Stawką w tej dyskusji jest przyszłość globalnej sieci - jej otwarty, wolny i niepodzielony charakter - z której użytkownicy będą mogli korzystać w bezpieczny sposób, ciesząc się swoimi prawami bez narażania się na utratę prywatności.

Unia Europejska jako znaczący członek społeczności międzynarodowej stara się aktywnie włączyć w dyskusje na temat przyszłości internetu. Przedstawiciele państw członkowskich i Komisji Europejskiej uczestniczą w pracach organizacji odpowiadających za zarządzanie internetem i poprzez wypracowywanie wspólnych stanowisk i strategii politycznych starają się kształtować proces zarządzania internetem.

Niniejszy artykuł podejmuje próbę wyjaśnienia specyfiki i istoty procesu zarządzania internetem, przedstawia genezę sporu pomiędzy zwolennikami wielostronnego modelu zarządzania internetem i państwami postulującymi wzmocnienie roli rządów w tym procesie oraz stanowisko Unii Europejskiej w tej debacie.

\section{SPECYFIKA I ISTOTA ZARZĄDZANIA INTERNETEM}

Internet ${ }^{4}$ to ogólnoświatowa sieć komputerowa, łącząca lokalne sieci korzystające z pakietowego protokołu komunikacyjnego TCP/IP, mająca jednolite zasady adresowania i nazywania węzłów (komputerów włączonych do sieci) oraz

3 Zob. Raport Komisji Nauki i Technologii na rzecz Rozwoju (Commission for Science and Technology for Development - CSTD), The mapping of international Internet public policy issues, http://unctad.org/meetings/en/SessionalDocuments/CSTD_2014_Mapping_Internet_en.pdf (dostęp z 12.03.2015).

${ }^{4}$ Często można spotkać się z zamiennym wykorzystaniem terminów internet i ogólnoświatowa sieć/pajęczyna (World Wide Web - WWW), jednak są to odmienne pojęcia. Ogólnoświatowa pajęczyną (WWW) to najpopularniejsza usługa udostępniania informacji w sieci internet lub intranet, z wykorzystaniem protokołu komunikacyjnego HTTP (HyperText Transfer Protocol) i języ- 
protokoły udostępniania informacji. ${ }^{5}$ Jest to techniczna, wąska definicja internetu. Jednak internet to nie tylko system protokołów i komputerów, to przede wszystkim system komunikacji pomiędzy użytkownikami. Takie ujęcie internetu jest szersze i (podobnie jak pozostałe systemy komunikacyjne, takie jak język czy telefon) daje możliwość wyróżnienia trzech warstw: fizycznej, logicznej i treści (rys. 1). ${ }^{6}$

Warstwa fizyczna to komputery, urządzenia i instrumenty umożliwiające komunikację. Są to narzędzia do produkcji i przekazywania informacji oraz szlaki komunikacyjne, czyli kable i sieci bezprzewodowe do transmisji danych.

Na warstwę fizyczną nakłada się warstwa logiczna, czyli protokoły, standardy techniczne i oprogramowanie, dzięki któremu warstwa fizyczna może funkcjonować jako narzędzie komunikacji. Mowa tutaj o kodzie komputerowym, który jest odpowiednikiem kodu komunikacyjnego. W tym znaczeniu kod służy do konstruowania i interpretowania wypowiedzi zarówno pomiędzy maszynami, maszyną a człowiekiem, jak i pomiędzy ludźmi. W przypadku internetu w warstwie kodu znajdują się protokoły transmisji danych, standardy telekomunikacyjne, a także oprogramowanie i usługi służące do tworzenia i przekazywania informacji w postaci cyfrowej.

Ostatnią warstwę stanowi treść internetu, czyli ostateczny komunikat - to, co jest faktycznie przekazywane za pomocą przewodów. W internecie w skład warstwy treści wchodzą przesyłane znaki - wiadomości przesyłane za pośrednictwem poczty elektronicznej, teksty, filmy, utwory muzyczne zapisane w postaci cyfrowej. ${ }^{\text {? }}$

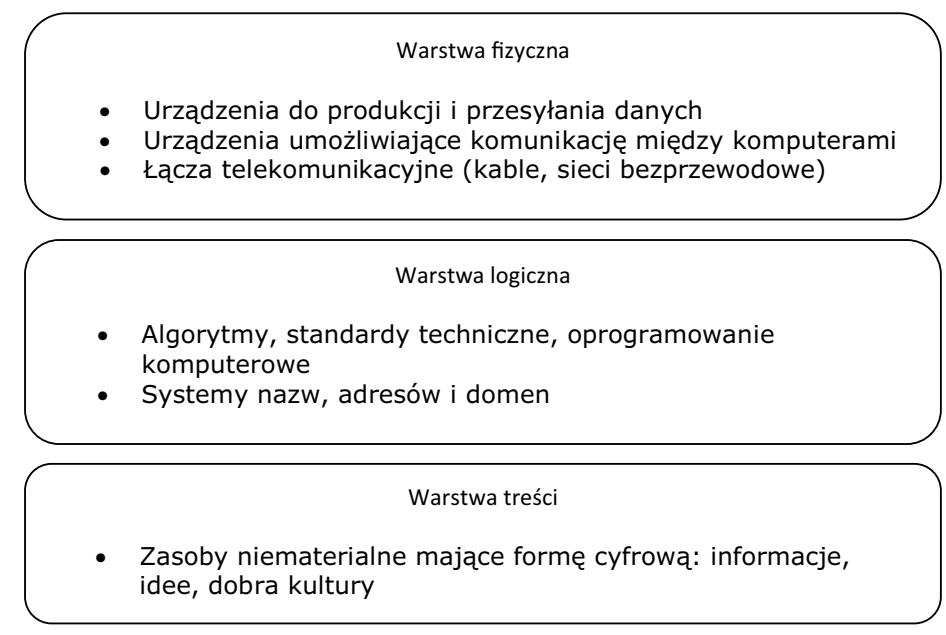

Rys. 1. Warstwy internetu

Źródło: J. Hofmolk, Internet jako nowe dobro wspólne, Warszawa 2009, s. 123

ka HTML (HyperText Markup Language); Encyklopedia PWN, hasło WWW, http://encyklopedia. pwn.pl/haslo/WWW;3998620.html (dostęp z 6.03.2015).

5 EncyklopediaPWN,hasłoInternet,http://encyklopedia.pwn.pl/haslo/Internet;3915155.html (dostęp z 6.03.2015).

6 J. Hofmolk, Internet jako nowe dobro wspólne, Warszawa 2009, s. 121.

7 Ibidem, s. 122-123. 
Te trzy warstwy internetu obejmują odpowiednio:

- funkcję technicznego zarządzania, która pozwala różnym elementom internetu na interakcję;

- techniczną koordynację kluczowych protokołów i adresów oraz numerów, które stanowią podstawę technicznego funkcjonowania internetu;

- prowadzenie spraw polityki społecznej, która powinna być przedmiotem otwartej dyskusji rządów, społeczeństwa obywatelskiego i przedsiębiorstw prywatnych. ${ }^{8}$

Wraz z rozwojem internetu ewoluował proces jego zarządzania. W początkowej fazie rozwoju koncepcja zarządzania internetem była utożsamiana ze środkami technicznymi niezbędnymi do zagwarantowania jego stabilności i dalszej ekspansji. Pojęcie zarządzania internetem ograniczone było do kwestii technicznych związanych z globalną synchronizacją i zarządzaniem nazwami domen i adresów IP. $Z$ biegiem czasu, gdy w połowie lat dziewięćdziesiątych internet stał się otwarty dla szerszej publiczności i, gdy stał się uniwersalnym medium dla informacji każdego rodzaju, definicja zarządzania internetem uległa znacznemu rozszerzeniu. ${ }^{9}$

W 2005 r. podczas Światowego Szczytu Społeczeństwa Informacyjnego (World Summit on Information Society - WSIS) ${ }^{10} \mathrm{w}$ Agendzie z Tunisu (Tunis Agenda) przyjęto roboczą definicję zarządzania internetem, która określa ten proces jako „rozwój oraz stosowanie przez rządy, sektor prywatny oraz społeczeństwo obywatelskie, odpowiednio w ramach ich zadań, wspólnych zasad, norm, reguł, procedur decyzyjnych oraz programów kształtujących rozwój i sposób korzystania z internetu”. ${ }^{11}$ Agenda z Tunisu kładzie nacisk na „,wielostronny, przejrzysty i demokratyczny proces, obejmujący rządy, sektor prywatny, społeczeństwo obywatelskie i organizacje międzynarodowe". ${ }^{12}$ Jest to dość szerokie ujęcie procesu zarządzania internetem, w którym poza zagadnieniami technicznymi pojawiają

${ }^{8}$ J. Kulesza, Międzynarodowe prawo internetu, Poznań 2007, s. 308.

9 J. Masters, What is Internet Governance?, http://www.cfr.org/internet-policy/internet-governance/p32843 (dostęp z 6.03.2013); J. Kurbalija, An Introduction to Internet Governance, Genewa 2014, s. 17.

${ }^{10}$ WSIS zorganizowano na podstawie rezolucji Zgromadzenia Ogólnego ONZ 56/183 z 21 grudnia 2001 r. Rezolucja przychyliła się do organizacji Światowego Szczytu Społeczeństwa Informacyjnego w dwóch fazach. Pierwsza odbyła się w Genewie w terminie od 10 do 12 grudnia $2003 \mathrm{r}$., druga miała miejsce w Tunisie i trwała od 16 do 18 listopada 2005 r. Celem pierwszej fazy było wypracowanie jasnego stanowiska woli politycznej oraz podjęcie konkretnych kroków w celu ustanowienia fundamentów społeczeństwa informacyjnego dla wszystkich, odzwierciedlającego różnorodność interesów. Celem drugiej fazy było wcielenie w życie Planu Działań z Genewy (Genewa Action Plan), a także znalezienie rozwiązań i osiągnięcie porozumień w dziedzinie zarządzania internetem, mechanizmów finansowania oraz działań następczych i implementacji dokumentów z Genewy i Tunisu.; Rezolucja Zgromadzenia Ogólnego ONZ 56/183, World Summit on the Information Society, http://www.itu.int/wsis/docs/background/resolutions/56_183_unga_2002.pdf (dostęp z 12.03.2015); Zob. Basic Information about WSIS, http://www.itu.int/wsis/basic/about.html (dostęp z 6.03.2015).

${ }^{11}$ Tunis Agenda For The Information Society, Document WSIS-05/TUNIS/DOC/6(Rev. 1)-E http://www.itu.int/wsis/docs2/tunis/off/6rev1.html (dostęp z 6.03.2015).

${ }^{12}$ Ibidem. 
się wartości, normy, procedury decyzyjne oraz całe spektrum podmiotów, które mają za zadanie określenie norm i procedur oraz sposobu ich wdrażania.

W związku z powyższym, o zarządzaniu internetem można mówić w ujęciu wąskim i szerokim. Ujęcie wąskie sprowadza się do kwestii infrastruktury internetu oraz standardów technicznych w oparciu o które funkcjonuje. W tym sensie chodzi głównie o dwie pierwsze warstwy internetu (fizyczną i logiczną) oraz o techniczne aspekty funkcjonowania warstwy treści, czyli standardy za pomocą których dane są przetwarzane i przesyłane w sieci, takie jak HTML ${ }^{13}$, czy SGML. ${ }^{14}$

$\mathrm{W}$ ujęciu szerokim zarządzanie internetem poza oczywistymi zagadnieniami technicznymi wkracza w szeroko rozumiane polityki społeczne, z którymi globalna sieć jest nierozłącznie związana (Internet public policy issues). Mowa tutaj o wszelkiego rodzaju zachowaniach związanych ze sposobem użytkowania internetu na poziomie warstwy treści. W najlepszy sposób ilustruje to tzw. sześcian zarządzania internetem (rys. 2). Jest to wizualizacja prezentująca złożoną, wielopłaszczyznową, wieloaspektową, wielopodmiotową/wielostronną (multistakeholder) i wielopoziomową charakterystykę zarządzania internetem.

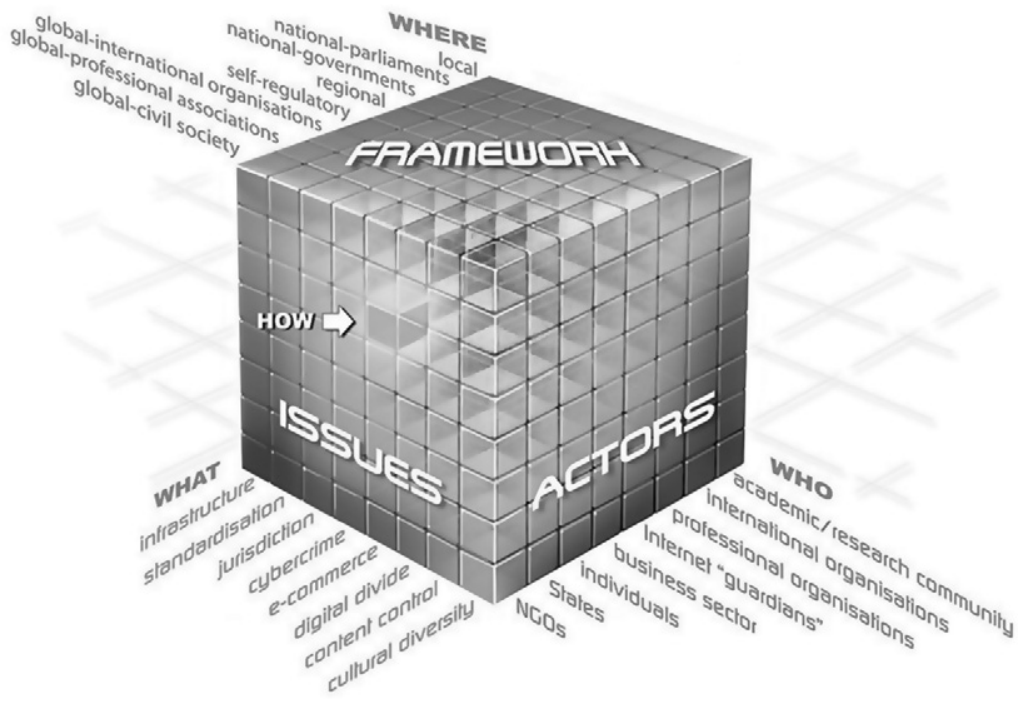

Rys. 2. Sześcian zarządzania internetem

Źródło: J. Kurbalija, An Introduction to Internet Governance, Genewa 2014, s. 200

${ }^{13}$ HTML (HyperText Markup Language) - język programowania używany do opisu informacji hipertekstowej (hipertekst) w sieci internet. Program w HTML jest przesyłany przez sieć i wykonywany przez tzw. Przeglądarkę, efektem czego na ekranie komputera zostaje wyświetlony obraz strony internetowej; Encyklopedia PWN, hasło HTML, http://encyklopedia.pwn.pl/haslo/ HTML;3912986.html (dostęp z 6.03.2015).

${ }^{14}$ SGML (Standard Generalized Markup Language)- język formalny określający sposób zapisu dokumentów zawierających sformatowany tekst oraz informacje nietekstowe (odnośniki do fragmentów dokumentu lub do innych dokumentów, rysunki itp.); Encyklopedia PWN, Hasło SGML, http://encyklopedia.pwn.pl/haslo/SGML;3974442.html (dostęp z 6.03.2015). 
Oś „Co” (What) wskazuje na obszary tematyczne, które obejmuje proces zarządzania internetem, w szczególności są to gospodarka (handel elektroniczny, opodatkowanie), bezpieczeństwo (cyberterroryzm, bezpieczeństwo sieci i jej użytkowników), technologia (zarządzanie częstotliwościami, rozwój standardów technicznych), społeczno-kulturowe (prawa człowieka, wolność wypowiedzi, zagadnienia związane z edukacją) itd. Płaszczyzna ta prezentuje wieloaspektowość procesu zarządzania internetem. Oś „Kto” (Who) wskazuje podmioty (państwa, organizacje międzynarodowe, społeczeństwo obywatelskie, sektor prywatny) uczestniczące w procesie zarządzania internetem uwidaczniając tym samym wielostronność tego procesu, w który zaangażowane są wszystkie podmioty życia społecznego. Oś „Gdzie" (Where) dotyczy regulacji normatywnych. Płaszczyzna ta szczególną uwagę zwraca na wielopoziomowy charakter norm (normy krajowe, normy organizacji regionalnych, traktaty międzynarodowe) mających zastosowanie do regulowania poszczególnych obszarów tematycznych w ramach których funkcjonuje internet.

Poruszając się w tak skonstruowanej przestrzeni zidentyfikować można wiele punktów, w których poszczególne płaszczyzny ulegają przecięciu. Punkty te mogą pomóc w poszukiwaniu odpowiedzi na pytanie „Jak” (How) poszczególne obszary tematyczne powinny być regulowane, przy użyciu jakich instrumentów prawnych, na jakim poziomie i przez które podmioty. Na przykład jedno z przecięć pozwala przeanalizować jak zagadnienie ochrony danych osobowych (co) zostało rozwiązane przez rządy, sektor prywatny i społeczeństwo obywatelskie (kto), na poziomie regionalnym (gdzie).

Z powyższych rozważań wyłania się dość skomplikowany obraz procesu zarządzania internetem. Jest on niewątpliwie złożony, trudny do opisania i zdefiniowania. Wynika to ze specyfiki i charakteru internetu, który jest siecią wielu sieci rozwijających się oddolnie przy udziale i zaangażowaniu wielu podmiotów, bez jakiejkolwiek nadrzędnej kontroli i centralnego ośrodka sterowania, i który wpływa na niemal każdy aspekt życia społeczno-gospodarczego.

\section{KONTROWERSJE WOKÓŁ WIELOSTRONNEGO MODELU ZARZĄDZANIA INTERNETEM}

Na potrzeby dalszej analizy przyjęte zostało wąskie rozumienie zarządzania internetem. Dla prowadzonych rozważań najważniejsza zdaje się być warstwa logiczna, ponieważ to ona określa kto odpowiada za sposób w jaki funkcjonuje Internet. Niezwykle istotne jest jej połączenie z warstwą treści. To na ich zbiegu funkcjonuje cyberspołeczność i to w jej obrębie znajdują się obecnie najbardziej kontrowersyjne kwestie procesu zarządzania internetem. Jest to o tyle istotne, że na poziomie warstwy kodu proces zarządzania opiera się o wypracowane już instytucje, zaś formuły współpracy w obrębie warstwy treści są dopiero w fazie inicjacji i wymagają wypracowania. ${ }^{15}$

${ }^{15}$ J. Kulesza, op. cit., s. 308. 
Na poziomie globalnym mamy do czynienia z szeregiem postulatów, które ukierunkowane są na zmianę obecnego sposobu zarządzania internetem, a więc już istniejących i wypracowanych rozwiązań. Można zaobserwować dwie sprzeczne tendencje: $\mathrm{z}$ jednej strony widoczne są działania ukierunkowane na zachowanie i rozwijanie wielostronnego modelu zarządzania internetem (zachowanie status quo z pewnymi modyfikacjami), z drugiej zaś próby jego osłabienia na rzecz zwiększenia zakresu kontroli i wpływu rządów państw na internet. Tocząca się debata ogniskuje się wokół kwestii tego kto powinien zarządzać internetem. Aby zrozumieć jej istotę konieczne jest przyjrzenie się głównym wydarzeniom, które przyczyniły się do jej obecnego kształtu.

Do 1998 r. internet był zarządzany praktycznie przez jednego człowieka. Jon Postel - profesor z Uniwersytetu Południowej Karoliny i jeden z twórców internetu zarządzał nim w imieniu Agencji Zaawansowanych Projektów Badawczych (Advanced Research Projects Agency - ARPA) Departamentu Obrony Stanów Zjednoczonych, jednak w połowie lat 90 stało się jasne, że taka sytuacja nie może trwać wiecznie. Po serii negocjacji pomiędzy przedstawicielami rządu, organizacji pozarządowych oraz przedsiębiorstw administracja Billa Clintona powołała do życia Internetową Korporację ds. Nadanych Nazw i Numerów (Internet Corporation for Assigned Names and Numbers - ICANN). ${ }^{16} 30$ stycznia 1998 r. wchodząca w skład Departamentu Handlu USA Krajowa Administracja ds. Telekomunikacji i Informatyzacji (National Telecommunications and Information Administration - NTIA) przedstawiła „Propozycję ulepszenia sposobu technicznego zarządzania nazwami i adresami internetowymi”. Dokument ten przedstawiał działania mające na celu prywatyzację zarządzania internetowymi nazwami i adresami przy jednoczesnym udziale $\mathrm{w}$ tym procesie organizacji z całego świata. Przyjęta polityka zakładała wyłączenie udziału poszczególnych państw z procesu zarządzania zasobami elektronicznymi, tak aby pozostawić ten obszar funkcjonowania sieci poza sporami politycznymi. ICANN powołano do życia 30 września 1998 r. na podstawie Memorandum of Understanding podpisanego z Departamentem Handlu USA na okres ośmiu lat, tym samym Korporacja stała się organizacją pozarządową typu non-profit działającą na podstawie prawa stanu Kalifornia. Niestety założenia przekazania kompetencji w ręce użytkowników sieci oraz wyłączenia rządowych wpływów wobec kluczowych kwestii procesu zarządzania siecią nigdy nie zostały w pełni osiągnięte. Porządek prawny oparty o Memorandum of Understanding i późniejsze umowy stawiał rząd Stanów Zjednoczonych w uprzywilejowanej pozycji dając Departamentowi Handlu pośrednią możliwość do wywierania wpływu na działania Korporacji. ${ }^{17}$

${ }^{16}$ K. N. Cukier, Who Will Control the Internet?, „Foreign Affairs”, tom 84, 2005 , nr 6.

${ }^{17} \mathrm{~J}$. Kulesza, Nowy rozdziat międzynarodowego zarzadzania internetem - Affirmation of Commitments, „Ruch prawniczy, ekonomiczny i socjalny”, 2010, nr 3 s. 53-55. 
Funkcje pełnione przez ICANN mają duże znaczenie na arenie międzynarodowej ${ }^{18}$, jednak na podstawie dotychczasowych porozumień rządy państw czy organizacje międzynarodowe nie miały dużego wpływu na decyzje jej zarządu. Fakt ten oraz późniejsze zachowanie Stanów Zjednoczonych doprowadziły do kryzysu międzynarodowego i spolaryzowania dyskusji o zarządzaniu internetem.

Za początek sporu i jednocześnie miejsce narodzin obecnej debaty o zarządzaniu siecią można uznać WSIS, podczas którego zgodzono się na szerokie ujęcie procesu zarządzania siecią i przyjęcie modelu wielostronnego, jednak trzy znaczące elementy spowodowały jego osłabienie i stały się przyczyną późniejszych wydarzeń.

Po pierwsze, w trakcie WSIS osiągnięto kompromis trudny do realizacji w praktyce. Sankcjonował funkcjonujący już i ukształtowany oddolnie (bottom-up) wielostronny model zarządzania internetem, jednak jednocześnie podważal go przez przypisanie poszczególnych ról różnym grupom podmiotów - ustanawianie polityk społecznych $\mathrm{w}$ obszarze internetu zostało powierzone $\mathrm{w}$ zasadzie wyłącznie rządom państw i organizacjom międzyrządowym, podczas gdy odpowiedzialność za kwestie techniczne i operacyjne internetu została powierzona sektorowi prywatnemu. Za warstwę treści odpowiadać miały rządy, natomiast za warstwę logiczną sektor prywatny. Spowodowało to swego rodzaju odseparowanie kwestii technicznych i polityk społecznych związanych z internetem, umieszczając tym samym rządy państw na szczycie „piramidy” zarządzania internetem i procesu decyzyjnego, czyli w miejscu, w którym nigdy wcześniej nie były i w roli, której nie sprawowały i nie sprawują do tej pory. ${ }^{19}$

Po drugie, WSIS nie przyjął jasnego stanowiska w sprawie ram instytucjonalnych decydujących o przyszłości globalnego zarządzania internetem. Decyzja w tym zakresie została odłożona w czasie i zastąpiona utworzeniem Forum Zarządzania Internetem (Internet Governance Forum - IGF), które do dziś pozostaje formułą luźnej wymiany opinii pomiędzy przedsiębiorcami, użytkownikami sieci, przedstawicielami społeczeństwa obywatelskiego i zazwyczaj nielicznie reprezentowanymi przedstawicielami rządów bez zdolności decyzyjnych..$^{20}$

Trzeci główny problem związany jest z wydarzeniami poprzedzającymi WSIS. Chodzi mianowicie o uprzywilejowaną pozycję Stanów Zjednoczonych. Pomimo iż w ciągu ostatnich 17 lat pierwotne porozumienie pomiędzy Departamentem Handlu USA a ICANN było kilkakrotnie zmieniane i wzmocnieniu uległa rola Rządowe-

${ }^{18}$ ICANN odpowiada m.in. za przyznawanie domen najwyższego stopnia (Top-level Domains - TLD) takich jak .ps dla Autonomii Palestyńskiej czy .tw dla Tajwanu. Kontrowersje budzą jego decyzje przyznające domeny podmiotom niecieszącym się międzynarodowym uznaniem; Zob. J. Kulesza, Umiędzynarodowienie Siecia globalna - konieczność czy fikcja?, „Monitor Prawniczy" 2007, nr 3, s. 41-50.

${ }^{19}$ F. Musiani, J. Pohle, NETmundial: only a landmark event if "Digital Cold War" rhetoric abandoned, „Internet Policy Review”, tom 3, 2014, nr 1, http://policyreview.info/articles/analysis/ netmundial-only-landmark-event-if-digital-cold-war-rhetoric-abandoned (dostęp z 12.03.2015).

${ }^{20}$ Ibidem. 
go Komitetu Doradczego ${ }^{21}$ (Governmental Advisory Committee - GAC) ICANN w procesie zarządzania internetem, Departament Handlu wciąż ma znaczący wpływ na Władzę ds. Przyznanych Numerów Internetowych ${ }^{22}$ (Internet Assigned Numbers Authority - IANA), która pełni znaczące funkcje techniczne w ramach ICANN. ${ }^{23}$

Pierwsza doniosła debata o kształcie zarządzania internetem została sprowokowana przez opublikowanie w czerwcu 2005 r. przez NTIA dokumentu zatytułowanego „Domain Names: U.S. Pronciple on the Internet's Domain Name Adressing System" "24, który jednoznacznie stwierdzał, że Stany Zjednoczone nie zamierzają zrezygnować z kontroli nad ICANN. Stanowisko takie argumentowane było koniecznością zagwarantowania należytego wykonywania przez ICANN swoich funkcji. Termin publikacji nieznacznie poprzedzał drugą fazę WSIS poświęconą m.in. wypracowaniu porozumienia w kwestii zarządzania Internetem, $\mathrm{z}$ tego też względu spotkanie w Tunisie stało się świetnym miejscem do poruszenia tej kwestii przez państwa sprzeciwiające się takiemu stanowisku USA. Ostatecznie podczas szczytu administracja prezydenta G. W. Busha nie pozostawiła złudzeń potwierdzając wcześniejsze plany - ICANN ma pozostać korporacją prywatną, działającą na terenie USA i podlegającą tamtejszemu prawu. ${ }^{25}$ Jednak w duchu kompromisu Stany Zjednoczone zgodziły się na powołanie do życia IGF. ${ }^{26}$

Kolejnym zagadnieniem, które w 2007 r. wywołało zaostrzoną debatę nad sposobem sprawowania nadzoru nad internetem i nazwami domenowymi, była kontrowersyjna decyzja ICANN w sprawie powstania nowego rozszerzenia ogólnej domeny najwyższego poziomu (gTLD) - .xxx, dedykowanej stronom o cha-

${ }^{21}$ Rządowy Komitet Doradczy jest częścią ICANN. GAC to organ doradczy Rady ICANN w sprawach związanych z politykami społecznymi w obszarze internetu, w szczególności doradza w kwestiach w których działania ICANN i jego polityka może oddziaływać na krajowe porządki prawne lub porozumienia międzynarodowe w kwestiach takich jak ochrona własności intelektualnej, egzekwowanie prawa, czy ochrona prywatności. Rada ICANN jest zobowiązana do rozpatrzenia rekomendacji GAC jednak nie jest zobowiązana do ich przestrzegania i realizacji. Członkowstwo w GAC jest otwarte dla przedstawicieli rządów, które wyrażą chęć udziału w jego pracach. Obecnie w GAC reprezentowanych jest 150 państw; L. G. Kruger, Internet Governance and the Domain Name System: Issues for Congress, s. 2, http://fas.org/sgp/crs/misc/R42351.pdf (dostęp z 12.03.2015).

${ }^{22}$ Władza ds. Przyznanych Numerów Internetowych - jest departamentem ICANN zapewniającym globalną koordynację kluczowych elementów internetu. IANA przydziela i utrzymuje unikalne kody i systemy numeracji, które są używane w normach technicznych (protokoły), które odpowiadają za funkcjonowanie internetu. Działania IANA grupują się w trzech kategoriach: nazwy domen (zarządzanie głównymi serwerami DNA, domenami int i arpa, zasób praktyk IDN), zasoby numeracji (koordynuje globalną pulę numerów IP i AS jak numery, przypisując je Regionalnym Rejestrom Internetowm) oraz przyznawanie protokołów (zarządza systemami numeracji IP wspólnie z organami standaryzacyjnymi); Introducing IANA, http://www.internetassignednumbersauthority.org/about (dostęp z 18.03.2015).

${ }^{23}$ F. Musiani, J. Pohle, op. cit.

${ }^{24}$ Zob. U.S. Principle on the Internet's Domain Name Adressing System http://www.ntia.doc. gov/files/ntia/publications/usdnsprinciples_06302005.pdf (dostęp z 9.03.2015).

${ }^{25} \mathrm{R}$. Cornwell, Bitwa o Internet, http://wiadomosci.onet.pl/prasa/bitwa-o-internet/ykmer (dostęp z 9.03.2015).

${ }^{26}$ L. G. Kruger, op. cit. s. 15. 
rakterze erotycznym. $Z$ jednej strony wydarzenie to sprowokowało dyskusję na temat ingerencji ICANN w kształtowanie polityki społecznej, a więc wtargnięcia na terytorium zarezerwowane dla rządów państw i organizacji międzynarodowych, z drugiej natomiast wyraźnie pokazało, że gdy pojawią się istotne kwestie, to o sposobie zarządzania internetem zdecydują Amerykanie. Sprawa wprowadzenia domeny .xxx została zablokowana przez Departament Handlu Stanów Zjednoczonych nadzorujący ICANN. ${ }^{2728}$

Powyższe wydarzenia stały się przyczynkiem do dyskusji na temat sposobu zarządzania globalną siecią i sposobem funkcjonowania jednego z jej kluczowych elementów - systemem nazw domenowych. Presja wokół ICANN narastała już od szczytu WSIS w Genewie, a późniejsze wydarzenia dostarczyły argumentów państwom opowiadającym się przeciwko amerykańskiej dominacji nad internetem (na czele tej grupy są Chiny, Rosja, Arabia Saudyjska, Iran). Chcą one by nadzór nad internetem przeszedł w ręce organu działającego pod egidą ONZ, aby każde państwo miało w nim swój udział. Częściowym sukcesem tych państw była zgoda Stanów Zjednoczonych podczas szczytu WSIS w Tunisie na powołanie IGF $^{29}$ organu działającego pod auspicjami Sekretarza Generalnego ONZ o charakterze globalnym, reprezentatywnego dla światowych rządów, pomocniczego w kwestiach zarządzania internetem jednak bez uprawnień decyzyjnych. ${ }^{30}$

W tej dyskusji Unia Europejska opowiedziała się po stronie państw sprzeciwiających się uprzywilejowanej pozycji Stanów Zjednoczonych. Wspólnota zaproponowała powołanie nowej organizacji do zarządzania internetem. Fakt ten stał się przyczyną jednego z głębszych kryzysów w stosunkach euroatlantyckich od dłuższego czasu. Jak powiedział przedstawiciel Departamentu Stanu USA obecny w Tunisie David Gross ,propozycja UE wydaje się przedstawiać historyczną zmianę $\mathrm{w}$ podejściu do regulacji internetu, oznaczającą przejście od modelu kontroli opartego o przewodnictwo sektora prywatnego do modelu zarządzania rządowego, nadzorującego". ${ }^{31}$ UE postulowała powołanie do życia nowej instytucji, która opracowałaby wytyczne określające jaki podmiot powinien otrzymać kontrolę nad adresami internetowymi i jaka byłaby jego rola przy tworzeniu międzynarodowego systemu rozstrzygania sporów internetowych. Postulat UE ukierunkowany był na funkcje sprawowane przez ICANN i miał na celu umiędzynarodowienie tej organizacji oraz zmianę sposobu jej nadzorowania. ${ }^{32}$

${ }^{27}$ J. Kurbalija, op. cit., s. 9.; J. Kulesza, Międzynarodowe prawo..., s. 324.

${ }^{28} \mathrm{~W}$ czerwcu 2010 r. ICANN zatwierdził wprowadzenie domeny .xxx; J. Kurbalija, op. cit., s. 31 .

${ }^{29} \mathrm{~W}$ grudniu 2010 r. Zgromadzenie Ogólne ONZ odnowiło mandat IGF na kolejne 5 lat oraz zleciło Komisji ds. Nauki i Technologii na rzecz Rozwoju działającej w ramach Rady Społecznej i Gospodarczej ONZ opracowanie raportu i zaleceń na temat sposobów poprawy funkcjonowania tego forum; L. G. Kruger, op. cit. s. 2.

${ }^{30}$ J. Kulesza, Międzynarodowe prawo..., s. 325-328.

${ }^{31}$ Ibidem.

${ }^{32}$ Ibidem. 
Zwolennicy utrzymania obecnego status quo zwracają uwagę na niebezpieczeństwa związane z przekazaniem internetu w gestię ONZ. Ich zdaniem sieć jest narzędziem szerzenia demokracji na całym świecie. Niepokojący jest zatem fakt, że wśród krajów najsilniej dążących do stworzenia międzynarodowej, zarządzanej odgórnie (top-down) struktury są państwa niepostrzegane powszechnie jako wzorce swobód obywatelskich. Państwom tym zależy na ograniczeniu dostępu obywateli do informacji i będą gotowe wprowadzić w życie swój cel także przy wykorzystaniu narzędzi ONZ. Tak więc teoretyczna demokratyzacja sieci w ramach systemu międzynarodowego może de facto skutkować poddaniem internetu ścisłej rządowej kontroli państw niedemokratycznych. ${ }^{33}$ Ponieważ jednak IGF jest tylko forum dyskusyjnym nieposiadającym rzeczywistego wpływu na decyzje podejmowane $\mathrm{w}$ sprawach funkcjonowania internetu państwa te nadal dążą do zwiększenia swojego wpływu na proces zarządzania globalną siecią.

Ów podział ujawnił się ponownie podczas Światowej Konferencji Telekomunikacji Międzynarodowej (World Conference on Inetnational Telecommunications - WCIT), która odbyła się w grudniu 2012 r. w Dubaju. Konferencja poświęcona była rewizji Międzynarodowych Regulacji Telekomunikacyjnych (International Telecommunication Regulations - ITR), które po raz ostatni były aktualizowane w 1988 r., czyli przed rozpowszechnieniem się internetu w jego obecnej formie. Jednym z powodów rewizji ITR był właśnie gwałtowny rozwój globalnej sieci. Dyskusje nad traktatem były burzliwe i ponownie doprowadziły do powstania dwóch grup państw zajmujących diametralnie odmienne stanowiska wobec zaproponowanych poprawek.

Rosja, Iran, Sudan, Chiny i szereg państw arabskich z rejonu Zatoki Perskiej sformułowały i dość spójnie promowały zbiór innowacji wprowadzających do ITR pojęcie internetu, a także zapewniających państwom „suwerenne prawo do tworzenia i wdrażania polityki publicznej, w tym polityki międzynarodowej, w sprawach zarządzania internetem"34, włączając w to zarządzanie systemami przydzielania adresów IP oraz DNS. Ponadto wspólnym punktem inicjatyw powstałej spontanicznie koalicji zwolenników suwerenności państwowej w sieci, promowanej przede wszystkim przez Rosję, stało się wzmocnienie roli Międzynarodowego Związku Telekomunikacyjnego (International Telecommunication Union - ITU), jednej z wyspecjalizowanych agend ONZ, w kwestiach globalnego zarządzania Internetem, włączając $\mathrm{w}$ to kwestie pośrednio związane $\mathrm{z}$ treścią, takie jak walka ze spamem.

\section{${ }^{33}$ Ibidem.}

${ }^{34}$ W. Rogacin, Wojna o kontrolę nad Internetem: Rządy dąża do zalegalizowania kontroli państwa nad siecia, http://www.polskatimes.pl/artykul/714879, wojna-o-kontrole-nad-internetem-rzady-daza-do-zalegalizowania-kontroli-panstwa-nad-siecia,id,t.html? cookie $=1,($ dostęp z 9.03.2015). 
Propozycje te spotkały się z krytyką ze strony kluczowych organizacji działających w ramach wielostronnego modelu zarządzania internetem (ISOC ${ }^{35}$, IGF $\mathrm{i}$ innych), jak i - w jeszcze większym stopniu - ze strony USA, Kanady, Australii oraz państw europejskich. Państwa te, wspierające model wielostronnego zarządzania Internetem, jako jedyny możliwy mechanizm zarządzania siecią oskarżyły Rosję, Chiny i ich sojuszników o próbę wyparcia sektora prywatnego oraz samej społeczności internetowej z procesu podejmowania globalnych decyzji w kwestii zarządzania internetem. Koncepcja suwerenności państwowej w „narodowym segmencie sieci internet" ${ }^{\prime 36}$ została odebrana jako sposób legalizacji cenzury w sieci oraz ograniczenia wolności słowa, dostępu do informacji i, co najgroźniejsze, do rozpadu globalnej sieci na sieci krajowe nadzorowane przez organy krajowe. Ze strony tych państw nie było również akceptacji dla pomysłu przeniesienia procesu zarządzania internetem na poziom ITU $^{37}$, który posiada tylko częściowy związek z internetem - na poziomie warstwy fizycznej i w ograniczonym zakresie na poziomie warstwy kodu. ${ }^{38}$

Spory i różnice zdań między stronnikami tych dwóch przeciwstawnych koncepcji zakończyły się fiaskiem konferencji. Za nowym tekstem Międzynarodowych Regulacji Telekomunikacyjnych zagłosowało 89 państw, zaś $55^{39}$ wstrzymało się od głosu, pozostawiając sobie w ten sposób możliwość postępowania zgodnie z poprzednią wersją ITR. W rezultacie społeczność międzynarodowa podzieliła się na dwa bloki, które dziennikarze i eksperci pozycjonowali odpowiednio jako „zwolenników wolności w internecie” i „adeptów suwerenności i cenzury internetowej”. I niezależnie od faktu, że wniesione ostatecznie do ITR

${ }^{35}$ Internet Society (ISOC) - jest organizacją pozarządową angażującą się w szerokie spektrum zagadnień internetowych, w tym polityk społecznych, zarządzania, technologii i rozwoju. Promuje otwarty rozwój, ewolucje i użytkowanie internetu z korzyścią dla wszystkich ludzi na świecie. Jest zaangażowana $\mathrm{w}$ działania techniczne takie jak rozwój standardów i protokołów, prowadzi akcje informacyjne i dostarcza wiedzy na temat funkcjonowania internetu oraz jego znaczenia dla rozwoju społeczno-gospodarczego, w szczególności państw rozwijających się, jest także forum wymiany poglądów $\mathrm{w}$ najistotniejszych sprawach związanych $\mathrm{z}$ funkcjonowaniem globalnej sieci. Zob. Who We Are, http://www.internetsociety.org/who-we-are (dostęp z 18.03.2015).

${ }^{36} \mathrm{~W}$. Rogacin, op. cit.

${ }^{37} 28$ listopada 2012 r. Rada Unii Europejskiej przyjęła decyzję ustanawiającą stanowisko UE do celów przeglądu Międzynarodowego Regulaminu Telekomunikacyjnego w którym m.in. stwierdza, że sprzeciwia się jakiemukolwiek rozszerzaniu obecnego mandatu ITU.; Proposal for a Council Decision establishing the European Union position for the review of the International Telecommunications Regulations to be taken at the World Conference on International Telecommunications or its preparatory process - Adoption, (ST-16217-2012-REV-1), http://data.consilium.europa.eu/doc/document/ST-16217-2012-REV-1/en/pdf (dostęp z 18.03.2015).

${ }^{38}$ O. Diemidow, Geopolityka cyberprzestrzeni - klasyczne koncepcje w nowym kontekście międzynarodowym, http://nowadebata.pl/2013/12/29/geopolityka-cyberprzestrzeni-klasyczne-koncepcje-w-nowym-kontekscie-miedzynarodowym/ (dostęp z 9.03.2015).

${ }^{39}$ Żadne z obecnych na konferencji państw Unii Europejskiej nie podpisało Międzynarodowego Regulaminu Telekomunikacyjnego; Signatories of the Final Acts: 89, http://www.itu.int/osg/ wcit-12/highlights/signatories.html (dostęp z 18.03.2015). 
poprawki nie przesądzały o przyszłości internetu i sposobie jego zarządzania, WCIT uznano za „cyfrową zimną wojnę"40 i „konferencję jałtańską 2,0"41, mając na myśli rozpoczynający się jakoby proces podziału kontroli nad siecią na korzyść Rosji, Chin i rozwijających się państw autorytarnych. W rzeczywistości jednak żaden sojusz ,adeptów cenzury w internecie” nie powstał, gdyż powstać nie mógł ze względu na dużą dynamikę wydarzeń oraz zmienne i wieloaspektowe interesy tych państw. Motywy ich działania są odmienne ${ }^{42} \mathrm{i}$ jedynie przejawiają się w bardzo zbliżony sposób odwołując się do podobnych rozwiązań. ${ }^{43}$

Kolejnym wydarzeniem, które ponownie podgrzało debatę wokół zarządzania internetem były sensacyjne doniesienia prasowe Washington Post z czerwca 2013 roku, oparte na informacjach przekazanych przez Edwarda Snowdena o powszechnej inwigilacji internetu przez amerykańską Agencję Bezpieczeństwa Narodowego (National Security Agency - NSA). Stanom Zjednoczonym udawało się do tej pory dość skutecznie odpierać działania innych państw na rzecz wzmocnienia ONZ lub jej organizacji wyspecjalizowanych, w zakresie zarządzania internetem, jednak skandal ujawniony przez Washington Post ponownie ożywił dyskusje na temat struktury tego procesu, pomimo iż ujawnione rewelacje nie mają wiele wspólnego z ICANN i sposobem w jaki funkcjonuje internet. Niemniej utrwaliły one przekonanie, że Waszyngton ma zbyt dużą władzę nad głównym dobrem globalnym jakim jest internet i wzmocniły postulaty radykalnych reform - dając państwom autorytarnym możliwość uzurpowania sobie kontroli nad istniejącymi normami i sposobem zarządzania internetem ${ }^{44}$, pozbawiając jednocześnie USA argumentu o konieczności zagwarantowania podstawowych praw w internecie.

Oburzone doniesieniami o rozległej inwigilacji internetowej NSA nawet liberalne państwa takie jak Brazylia ${ }^{45}$ i Niemcy poddały pod rozwagę konieczność „nacjonalizacji” niektórych elementów infrastruktury internetowej. Kanclerz

${ }^{40}$ Zob. A digital cold war?, http://www.economist.com/blogs/babbage/2012/12/internet-regulation (dostęp z 9.03.2015); N. Kroes, Stopping the Digital Cold War, Przemówienie z 28 lutego 2013 r., http://europa.eu/rapid/press-release_SPEECH-13-167_en.htm (dostęp z 9.03.2015).

${ }^{41}$ Zob. A. Klimburg, The Internet Yalta. Center for a new American Security, http://www. cnas.org/files/documents/publications/CNAS_WCIT_commentary.pdf (dostęp z 9.03.2015).

${ }^{42}$ Zob. J. Kulesza, NETmundial - mecz o przyszłość sieci, http://stosunki.pl/?q=content/netmundial-\%E2\%80\%93-mecz-o-przysz $\%$ C5\%82o\%C5\%9B\%C4\%87-sieci (dostęp z 14.03.2015).

${ }^{43}$ O. Diemidow, op. cit.

${ }^{44}$ S. L. Pettyjohn, Net Gain. Washington Cedes Control of ICANN, http://www.foreignaffairs. com/articles/141122/stacie-l-pettyjohn/net-gain (dostęp z 14.03.2015).

${ }^{45}$ Prezydent Brazylii Dilma Rousseff zapowiedziała zdecydowane działania zmierzające do ukrócenia samowoli rządu Stanów Zjednoczonych w globalnej sieci. Bezpośrednio po doniesieniach o programie PRISM wyraziła wolę „odcięcia” Brazylii od globalnej sieci i zastąpienia międzynarodowego internetu krajowym intranetem, pilnie strzeżonym przed obcymi służbami. Takie stanowisko wpisywało się co prawda w wieloletnią politykę Brazylii zmierzającą do zagwarantowania praw człowieka $\mathrm{w}$ internecie, jednak doniesienia o praktykach NSA doprowadziły do jej intensyfikacji i przyjęcia przez brazylijski parlament w marcu 2014 roku „Ustawy obywatelskiej o internecie" (Marco Civil da Internet), która została podpisana przez Prezydent Rousseff podczas konferencji NETmundial; J. Kulesza, NETmundial ... 
Niemiec Angela Merkel mówiła nawet o utworzeniu „europejskiego internetu” i konieczności przekonania do takiego pomysłu Françoisa Hollanda, prezydenta Francji, po to aby stworzyć europejską alternatywę wobec dominacji USA w kwestiach infrastruktury internetowej. ${ }^{46}$

Wydarzenia te poprzedziły szczyt NETmundial zorganizowany z inicjatywy prezydent Brazylii Dilmy Rousseff. Szczyt poświęcony był sprawom zarządzania internetem, uczestniczyło w nim ponad 1400 osób z 97 państw, przedstawiciele rządów, przedsiębiorców, społeczeństwa obywatelskiego oraz środowiska akademickiego. NETmundial opisywany był jako „ogólnoświatowe wielostronne spotkanie na temat przyszłości zarządzania internetem". ${ }^{47}$ Spotkanie było otwarte dla wszystkich zainteresowanych stron i miało „skupić się na opracowaniu zasad zarządzania internetem i zaproponować mapę drogową na rzecz dalszego rozwoju ekosystemu zarządzania internetem". ${ }^{48}$

Rezultatem spotkania stał się niewiążący dokument „Wielostronna deklaracja NETmundial”49, w której przyjęto ogólne zasady zarządzania internetem oraz zidentyfikowano obszary do dalszej dyskusji podczas przyszłych spotkań poświęconych procesowi zarządzania internetem. Dokument potwierdził wielostronny model zarządzania internetem, wyraził poparcie dla zobowiązania Stanów Zjednoczonych do przekazania nadzoru nad funkcjami sprawowanymi przez IANA na rzecz ogólnoświatowej społeczności ${ }^{50}$, kładł nacisk na wzmocnienie i przedłużenie mandatu IGF oraz podkreślał znaczenie praw człowieka w procesie osiągnięcia całkowicie wolnego i otwartego internetu. ${ }^{51}$

Podczas dwóch dni szczytu nie osiągnięto jednak znaczących rezultatów. Postanowienia deklaracji nie zaspokajały postulatów wszystkich zainteresowanych stron. Sam szczyt miał charakter zbliżony do konferencji międzyrządowej niż spotkania entuzjastów internetu i zdaniem silnie reprezentowanego społeczeństwa obywatelskiego nie spełnił ich oczekiwań, chociażby w kwestii poparcia dla

${ }^{46}$ J. Vasagar, J. Fontanella-Khan, Angela Merkel backs EU internet to deter US spying, http:// www.ft.com/intl/cms/s/0/dbf0081e-9704-11e3-809f-00144feab7de.html\#axzz3TtzWILun (dostęp z 9.03.2015).

${ }^{47}$ NETmundial, http://netmundial.br/about (dostęp z 14.03.2015).

${ }^{48}$ Ibidem.

${ }^{49}$ Zob. NETmundial Multistakeholder Statement, http://netmundial.br/wp-content/uploads/ 2014/04/NETmundial-Multistakeholder-Document.pdf (dostęp z 14.032015).

${ }^{50}$ Krajowa Administracja ds. Telekomunikacji i Informatyzacji (NITA) poinformowała 14 marca 2014 r., że planuje przekazanie od września 2015 r. kluczowych funkcji związanych z zarządzaniem domenami internetowymi społeczności międzynarodowej. Departament Handlu USA dał jasno do zrozumienia, że opowiada się za utrzymaniem wielostronnego modelu zarządzania siecią i nie przekaże kluczowych funkcji zarządzania internetem organizacji kierowanej przez inny rządu lub grupę państw.; NTIA Announces Intent to Transition Key Internet Domain Name Functions, http://www.ntia.doc.gov/press-release/2014/ntia-announces-intent-transition-key-internet-domain-name-functions (dostęp z 18.03.2015), Zob. Doing the ICANN-can, http:// www.economist.com/news/international/21599385-america-promises-release-its-grip-internets-phone-bookand-opens-up-debate (dostęp z 14.03.2014).

${ }^{51}$ L. G. Kruger, op. cit., s. 27. 
idei neutralności sieci, która z kolei jest mocno kontestowana przez niektórych dostawców usług - przedstawicieli sektora ICT, którzy także mieli większe oczekiwania wobec spotkania. ${ }^{52}$ Niezadowolenie było również widoczne po stronie państw, w szczególności tych które postulują zwiększenie roli rządów w procesie zarządzania internetem. Państwa takie jak Rosja, Chiny, czy Indie odmówiły podpisania „Wielostronnej deklaracji NETmundial” uznając jej postanowienia za niejednoznaczne i bezwartościowe. ${ }^{53}$

NETmundial jest dowodem na brak spójnych ram instytucjonalnych. Społeczność międzynarodowa podejmuje próby rozwiązania najistotniejszych problemów poza organizacjami i forami funkcjonującymi w obrębie obecnego wielostronnego modelu zarządzania internetem.

W ten oto sposób kwestie zarządzania globalną siecią, główne obawy oraz nadzieje z nimi związane w dalszym ciągu pozostają nierozstrzygnięte. Konieczność zmian w ramach wielostronnego modelu zarządzania jest coraz bardziej widoczna. W najbliższym czasie pojawi się kolejna szansa na ich przeprowadzenie. ${ }^{54}$ Pojawia się jednak pytanie czy zostanie ona wykorzystana, czy stanie się przedmiotem kolejnej dyskusji i dalszej polaryzacji stanowisk.

\section{STANOWISKO UNII EUROPEJSKIEJ WOBEC PROCESU ZARZĄDZANIA INTERNETEM}

W toczącej się debacie na temat zarządzania internetem wyróżnić można dwie tendencje: $z$ jednej strony zauważalne jest poszanowanie i ochrona wielostronnego modelu zarządzania internetem, $\mathrm{z}$ drugiej coraz bardziej widoczny jest trend do zwiększania zakresu kontroli i wpływu rządów na internet.

Unia Europejska dąży do ochrony i zreformowania wielostronnego modelu zarządzania internetem. $Z$ jednej strony opowiada się za umiędzynarodowieniem funkcji sprawowanych przez ICANN, z drugiej zaś za wzmocnieniem obecnego modelu zarządzania internetem, tak aby proces ten był oparty na przejrzystym i zapobiegającym wykluczeniu modelu zarządzania $\mathrm{z}$ udziałem wielu zainteresowanych stron, z wyraźnie określonym zakresem odpowiedzialności. Takie

${ }^{52}$ An online Risorgimento, http://www.economist.com/blogs/babbage/2014/04/internet-governance (dostęp z 14.03.2015).

${ }^{53}$ J. Kulesza, NETmundial...

${ }^{54}$ Agenda z Tunisu wzywa Zgromadzenie Ogólne ONZ do przeprowadzenia generalnego przeglądu procesu WSIS w 2015 r. 31 lipca 2014 r. ZO ONZ przyjęło rezolucję 68/302, określając warunki dla ogólnego przeglądu rezultatów WSIS. Zdecydowano, że przegląd odbędzie się w ramach dwudniowego spotkania ZO ONZ wysokiego szczebla zaplanowanego na grudzień 2015 r.; Rezolucja Zgromadzenia Ogólnego ONZ 68/302, Modalities for the overview by the General Assembly of the implementation of the outcomes of the World Summit on the Information Society, (A/RES/68/302), http://www.un.org/en/ga/search/view_doc.asp?symbol=A/RES/68/302 (dostęp z 17.03.2015). 
dwutorowe podejście Unii Europejskiej do problemu zarządzania internetem jest widoczne w jej działaniach i dokumentach programowych.

Podczas drugiej fazy Światowego Szczytu Społeczeństwa Informacyjnego w 2005 r. Unia Europejska dała wyraz swojemu podejściu do roli ICANN w procesie zarządzania internetem i pozycji Stanów Zjednoczonych. W maju 2009 r., Komisarz UE ds. Mediów i Społeczeństwa Informacyjnego, Viviane Reding, potwierdziła stanowisko UE wskazując na potrzebę pełnej prywatyzacji i uniezależnienia ICANN oraz poddania organizacji mechanizmom międzynarodowej kontroli. Konieczność tę Komisarz Reding uzasadniła charakterem ICANN, stanowiącym o jej pozycji światowego monopolisty, który jako taki nie powinien podlegać władzy tylko jednego rządu. ${ }^{55}$

Z kolei w Dubaju w trakcie WCIT podczas dyskusji na temat zarządzania internetem państwa europejskie jednoznacznie opowiedziały się za ochroną wielostronnego modelu zarządzania globalna sieciąa $\mathrm{i}$ przeciwstawiły się wszelkim próbom przejęcia nad nim kontroli przez państwa autorytarne.

Oficjalne dokumenty Unii Europejskiej podkreślają potrzebę reformy sposobu w jaki zarządzany jest internet. W swoim komunikacie z 12 lutego $2014 \mathrm{r}$. Komisja Europejska przedstawia wizję działań na rzecz utrzymania i wzmocnieniem obecnie funkcjonującego modelu. Podobny wydźwięk mają także konkluzje Rady ds. Transportu Telekomunikacji i Energii przyjęte 27 listopada 2014 r., które w znacznej mierze uwzględniają propozycje Komisji Europejskiej.

Za najgroźniejsze zagrożenia dla internetu Komisja Europejska uznała utratę zaufania użytkowników do sieci wynikającą m.in. z ujawnionych w ostatnim czasie programów masowego nadzoru oraz obaw przed cyberprzestępczością. Taka utrata zaufania może skutkować spowolnieniem innowacji i wzrostu europejskich przedsiębiorstw internetowych doprowadzając jednocześnie do nacisków ze strony państw na rzecz utworzenia nowych regionalnych i krajowych struktur zarządzania, co w konsekwencji mogłoby zakończyć się fragmentacją internetu.

W swoich dokumentach zarówno Komisja Europejska jak i Rada dają wyraz konieczności ochrony i propagowania praw podstawowych i wartości demokratycznych oraz struktur zarządzania internetem $\mathrm{z}$ udziałem wielu zainteresowanych stron, których funkcjonowanie opiera się na zasadach poszanowania tych praw i wartości. Internet ma pozostać jednolitą niepodzieloną siecią, podlegającą tym samym przepisom i normom, jakie są stosowane w innych obszarach codziennego życia, w której jednostki mogą korzystać ze swoich praw oraz ze środków zaskarżenia w przypadku ich naruszenia. Natomiast wszelkie dyskusje międzyrządowe osadzone winny być w kontekście wielostronnym z pełnym zrozumieniem, że

${ }^{55}$ J. Kulesza, Międzynarodowe prawo..., s. 325.

${ }^{56} \mathrm{~J}$. Kurbalija, The EU on Internet governance: Strong on description - Weak on prescription, http://www.diplomacy.edu/blog/eu-internet-governance-strong-description-\%E2\%80\%93weak-prescription (dostęp z 6.03.2015). 
internet jest tworzony i utrzymywany przez całe spektrum podmiotów wśród których są także rządy państw.

Celem Unii Europejskiej jest usprawnienie wielostronnego modelu zarządzania internetem tak, aby zachować uniwersalny, otwarty i wolny charakter internetu, w którym respektowane będą prawa człowieka i podstawowe wolności. Unii Europejskiej w szczególności zależy na:

- ustanowieniu wspólnie ze wszystkimi zainteresowanymi stronami spójnego zbioru powszechnych zasad zarządzania internetem. Komisja propaguje podejście określane skrótem COMPACT, zgodnie z którym internet jest przestrzenią odpowiedzialności obywatelskiej (Civic responsibilities), jednym niepodzielnym zasobem (One unfragmented resource) zarządzanym za pomocą podejścia z udziałem wielu zainteresowanych stron (Multistakeholder approach) w celu wspierania demokracji i praw człowieka (Promote democracy and Human Rights) w oparciu o solidną architekturę techniczną (Architecture), która jest źródłem zaufania (Confidence) i sprzyja przejrzystości zarządzania (Transparent governance) zarówno bazową infrastrukturą internetu, jak i usługami wykonywanymi przy jej użyciu.

- ustaleniu sposobów zglobalizowania funkcji IANA, przy jednoczesnym zapewnieniu ciągłej stabilności i bezpieczeństwa systemu nazw domen oraz ustanowieniu jasnego harmonogramu w odniesieniu do globalizacji ICANN, włącznie z potwierdzeniem jej zobowiązań. Komisja jest świadoma historycznych uwarunkowań obecnego związku ICANN z rządem USA, jednak w dobie rozpowszechnionego użycia internetu, który spełnia ważną funkcję wspierania społeczeństwa i gospodarki na całym świecie sytuacja taka musi ulec zmianie.

- jasnym określeniu roli podmiotów w procesie zarządzania internetem, w tym władz publicznych, zgodnej z otwartym i wolnym charakterem internetu. Takie zrównoważone podejście wymaga wspólnego zobowiązania się wszystkich zainteresowanych stron do przestrzegania spójnego zestawu zasad zarządzania internetem. Niezbędne są również mechanizmy odpowiedzialności podmiotów w cyberprzestrzeni, w tym organizacji odpowiedzialnych za kluczowe zadania internetu.

- wzmocnieniu globalnego Forum Zarządzania Internetem (IGF). Ze względu na globalne gospodarcze i społeczne znaczenie internetu niezbędny jest dialog oparty na wzajemnym szacunku między wszystkimi zainteresowanymi stronami w sprawie przyszłego rozwoju światowego zarządzania Internetem. Funkcje tą wypełnia IGF, który jednak musi zostać odpowiednio wzmocniony, m.in. poprzez przyznanie mu bezterminowego mandatu oraz zapewnienie odpowiedniego poziomu finansowania jego prac.

- wzmocnieniu zrównoważonego charakteru wielostronnego modelu zarządzania internetem, który byłby bardziej przejrzysty, zapobiegałby wykluczaniu słabszych podmiotów lub dominacji ze strony silniejszych, 
gwarantowałby ich odpowiedzialność i włączał jak najszersze grono zainteresowanych,

- uruchomieniu Globalnego Obserwatorium ds. Polityki wobec Internetu (Global Internet Policy Observatory - GIPO), platformy internetowej gromadzącej informacje na temat najważniejszych wydarzeń związanych $\mathrm{z}$ internetem. Zadaniem GIPO będzie stworzenie globalnego narzędzia internetowego do monitorowania procesu kształtowania polityki wobec internetu, regulacji i technologii. Ma to pomóc w ustaleniu powiązań między różnymi forami i dyskusjami, tak aby przezwyciężyć „silosy organizacyjne" oraz osadzić informacje we właściwym kontekście. Ułatwiłoby to wszystkim zainteresowanym, dysponującym ograniczonymi środkami, śledzenie kwestii związanych z zarządzaniem internetem i polityką wobec niego, zrozumienie tych zjawisk oraz zaangażowanie się w nie.

- poszukiwaniu rozwiązań dla problemu jakim jest kwestia jurysdykcji i stosowania prawa wobec ponadnarodowego charakteru internetu. Internet jako transgraniczne medium stwarza szereg wyzwań w zakresie stosowania przepisów prawa. Ich złożoność i, w niektórych przypadkach, brak przejrzystości stosowanych rozwiązań, w szczególności przepisów dotyczących właściwej jurysdykcji i prawa, może doprowadzić do braku pewności prawa. Ilość różnego rodzaju transakcji transgranicznych, które odbywają się w internecie, wymaga bardziej dogłębnego zastanowienia się nad tym, w jaki sposób obowiązujące przepisy stosują się w odniesieniu do internetu. ${ }^{57}$

Powyższe postulaty ponowiono podczas dziewiątego dorocznego spotkania IGF, które odbyło się we wrześniu 2014 r. w Stambule. Neelie Kroes, wiceprzewodnicząca Komisji Europejskiej odpowiedzialna za Agendę Cyfrową, potwierdziła stanowisko prezentowane przez Unię Europejską, opowiadając się za rozpoczęciem reform obecnego modelu, wzmocnieniem pozycji IGF, globalizacją ICANN i funkcji sprawowanych przez IANA, a wszystko to w oparciu o zestaw zasad propagowanych przez Unię Europejską i przyjętych podczas szczytu NETmundial. $^{58}$

W jednej z najważniejszych i najbardziej kontrowersyjnych spraw związanych z zarządzaniem internetem Unia Europejska niemalże od początku dyskusji

${ }^{57}$ Komunikat Komisji do Parlamentu Europejskiego, Rady, Europejskiego Komitetu Ekonomiczno-Społęcznego i Komitetu Regionów, Polityka wobec internetu i zarządzania internetem, Rola Europy w ksztaltowaniu przyszłości zarzadzania internetem, COM(2014) 72 final, http:// eur-lex.europa.eu/legal-content/PL/TXT/HTML/?uri=CELEX:52014DC0072\&from=EN (dostęp z 18.03.2015); Rada ds. Transportu, Telekomunikacji i Energii, Council conclusions on Internet Governance, 16200/14, http://data.consilium.europa.eu/doc/document/ST-16200-2014-INIT/en/ pdf (dostęp z 18.03.2015).

${ }^{58}$ Przemówienie wygłoszone podczas ceremonii otwarcia IGF w Istambule, N. Kroes, Defending the open Internet, http://europa.eu/rapid/press-release_SPEECH-14-576_en.htm (dostęp z 18.03.2015). 
zajmowała jasne stanowisko - ICANN powinien zostać oddany pod kontrolę społeczności międzynarodowej, a sytuacja w której jedno państwo cieszy się uprzywilejowana pozycją nie powinna mieć miejsca, w szczególności w przypadku tak istotnego dobra jakim jest internet. Niestety takie podejście zdaje się zatrzymywać w połowie drogi, brak jest bowiem konkretnych rozwiązań, mówiących o tym, jak miałoby wyglądać umiędzynarodowienie funkcji ICANN i jaki podmiot powinien przejąć nad nim kontrolę.

Innym ważnym elementem stanowiska UE na który warto zwrócić uwagę jest zagrożenie związane z możliwością uzyskania dominującej pozycji przez podmioty silne finansowo i organizacyjnie $\mathrm{w}$ wielostronnym modelu zarządzania. Przeciwdziałanie takiej sytuacji zazwyczaj związane jest $\mathrm{z}$ wprowadzaniem mechanizmów ochronnych, procedur bądź instytucji, których zadaniem jest zabezpieczenie interesów najsłabszych oraz stworzenie porównywalnych dla wszystkich warunków udziału w całym procesie. W tym przypadku wprowadzanie mechanizmów równowagi i kontroli może okazać się trudne. Trzeba zachować odpowiedni balans pomiędzy wprowadzanymi rozwiązaniami i jednocześnie starać się unikać nadmiernej rozbudowy struktur instytucjonalnych, aby nie przeregulować systemu. Paradoksalnie ociężałość struktur i rozproszony proces decyzyjny UE może okazać się wartościowym doświadczeniem we wzmacnianiu wielostronnego modelu zarządzania internetem. W tym kontekście istotne jest również jasne określenie roli podmiotów uczestniczących w procesie, aby uniknąc sytuacji podobnych do tej która miała miejsce z powstaniem domeny .xxx.

Unia Europejska słusznie zauważa także konflikt jurysdykcji i przepisów prawa. Wbrew powszechnej opinii dostrzega, że jednak internet „zna” granice. Problem nie jest jakościowy a ilościowy. Użytkownicy, sprzęt komputerowy, przesyłane dane przekraczają granice jednak nie oznacza to, że nie są możliwe do zlokalizowania i geograficznego przypisania, jednak ich ilość i różnorodność wymaga lepszej analizy jak obowiązujące przepisy mogą być egzekwowane w praktyce. W tym punkcie stanowisko UE zdaje się jednak skupiać jedynie na aspektach związanych $\mathrm{z}$ handlem elektronicznym pomijając zagadnienia ochrony prywatności, naruszenia dóbr osobistych czy podatków.

Wreszcie stworzenie GIPO i wzmocnienie IGF może pomóc ustrukturyzować dyskusje związane z zarządzaniem internetem. $\mathrm{Z}$ jednej strony unika się poszukiwania nowych forów w ramach których omawiane będą najistotniejsze tematy (przypadek NETmundial) i ryzyka wykluczenia niektórych podmiotów. Wzmocniona zostanie przejrzystość procesu i dostęp do informacji, co może pomóc w lepszym jego zrozumieniu przy jednoczesnym wyrównaniu szans najsłabszych podmiotów. ${ }^{59}$

Unia Europejska ma właściwą pozycję aby odegrać istotną rolę w rozmowach o przyszłym kształcie wielostronnego modelu zarządzaniu internetem, gdyż stale się rozwija w kierunku nowoczesnego społeczeństwa sieci z rozproszonymi

\footnotetext{
${ }^{59} \mathrm{~J}$. Kurbalija, The EU on Internet...
} 
ośrodkami sprawowania władzy i podejmowania decyzji. Próba urzeczywistnienia wzmocnienia wielostronnego modelu zarządzania internetem jest realizowana przez budowanie koalicji tematycznych, gdzie z jednej strony UE wywiera presję na Stany Zjednoczone, z drugiej zaś zgłasza szereg postulatów na rzecz umocnienia wielostronnego modelu zarządzania internetem i stanowczo sprzeciwia się wszelkim pomysłom ukierunkowanym na wzrost roli państw i przekazaniu kontroli nad nim instytucjom międzyrządowym.

Inicjatywy Unii Europejskiej w obszarze społeczeństwa informacyjnego i gospodarki cyfrowej zawsze śledzone są z dużą uwagą. Powodem tego jest potencjał Unii Europejskiej reprezentowany przez rynek ponad 500 mln konsumentów z których $62 \%$ korzysta regularnie z internetu. ${ }^{60}$ Owo zainteresowanie przejawia się niespotykaną koncentracją lobby sektora technologii informacyjnych i komunikacyjnych w Brukseli. Takie przedsiębiorstwa jak Facebook czy Google ${ }^{61}$ negocjując $\mathrm{z}$ UE kwestie antymonopolowe czy ochrony danych osobowych negocjują $\mathrm{z}$ resztą świata, ponieważ uzgodnienia zawarte z UE są bardzo często inspiracją dla innych państw i regionów do podjęcia podobnych działań. Co prawda w UE nie ma firm o globalnym zasięgu i takiej pozycji rynkowej jak przedsiębiorstwa amerykańskie z Doliny Krzemowej, jednak paradoksalnie ta słabość może okazać się siłą UE jeśli chodzi o zarządzanie internetem. Brak konieczności ochrony interesów gospodarczych branży internetowej daje UE większą swobodę w promowaniu i ochronie interesu publicznego (prawa użytkowników, neutralności sieci itp.). W ten sposób UE może stać się mediatorem w debacie o przyszłym modelu zarządzania internetem, który opowiada się za reformą obecnego modelu zarządzania internetem i jest jednocześnie jego promotorem. UE może zatem osiągnąć sukces moralny przy jednoczesnej realizacji celów strategicznych, co nie jest częstym zjawiskiem w polityce międzynarodowej. ${ }^{62}$

\section{PODSUMOWANIE}

W proces zarządzania internetem zaangażowanych jest wiele podmiotów, każdy z nich ma swoje interesy i podejmuje próby ich realizacji. Dodatkowo sama specyfika i charakter internetu komplikują dyskusje związane ze sposobem jego regulacji i funkcjonowania.

Dla skutecznego zarządzania siecią potrzebny jest kompromis wszystkich grup zaangażowanych w jej funkcjonowanie: użytkowników, dostawców usług

${ }^{60}$ Digital Inclusion and Skills, http://ec.europa.eu/digital-agenda/en/news/scoreboard-2014digital-inclusion-and-skills-eu-2014 (dostęp z 11.03.2015).

${ }^{61}$ Zob. Wyrok Trybunału Sprawiedliwości Unii Europejskiej z dnia 13 maja 2014 r. w sprawie C-131/12, Google Spain SL, Google Inc. przeciwko Agencia de Protección de Datos (AEPD), Mario Costeja González, http://curia.europa.eu/juris/liste.jsf?language=pl\&num=C-131/12 (dostęp z dnia 11.03.2015).

${ }^{62} \mathrm{~J}$. Kurbalija, The EU on Internet... 
i państw, regulujących przy pomocy instrumentów prawnych zachowania i zaniechania tych dwóch pierwszych grup. Internet z racji swojej zdecentralizowanej architektury, inaczej niż jakiekolwiek inne medium, nie poddaje się odgórnej regulacji, właściwej krajowej strukturze prawnej. Nie pasuje do niego także schemat tworzenia prawa międzynarodowego, negocjowanego przez państwa za zamkniętymi drzwiami dyplomatycznych konferencji. ${ }^{63}$ Zdaje się to potwierdzać tocząca się debata pomiędzy zwolennikami poszanowania, ochrony i wzmocnienia wielostronnego modelu zarządzania internetem a państwami dążącymi do zwiększania swojego zakresu kontroli i wpływu na internet.

Unia Europejska dostrzega te kwestie i jako jeden ze znaczących podmiotów na arenie międzynarodowej może w tej dyskusji odegrać kluczową rolę stając się mediatorem w debacie o przyszłym modelu zarządzania internetem. Próby podejmowane przez państwa członkowskie UE oraz jej instytucje (głównie KE), mają na celu ochronę i wzmocnienie wielostronnego modelu zarządzania internetem. Poszukiwane są sposoby na odnalezienie złotego środka, który stanie się kompromisem pomiędzy postulatami wzmocnienia roli rządów, a zachowaniem uniwersalnego, otwartego i wolnego charakter internetu, w którym respektowane będą prawa człowieka i podstawowe wolności.

\section{BIBLIOGRAFIA}

1. A digital cold war?, http://www.economist.com/blogs/babbage/2012/12/internet-regulation (dostęp z 9.03.2015);

2. Abbate J., Inventing the Internet, Cambridge 1999.

3. An online Risorgimento, http://www.economist.com/blogs/babbage/2014/04/internet-governance (dostęp z 14.03.2015).

4. Basic Information about WSIS, http://www.itu.int/wsis/basic/about.html (dostęp z 6.03.2015).

5. Cornwell R., Bitwa o Internet, http://wiadomosci.onet.pl/prasa/bitwa-o-internet/ykmer (dostęp z 9.03.2015).

6. Cukier K. N., Who Will Control the Internet?, „Foreign Affairs”, tom 84, 2005 , nr 6.

7. Kroes N. Defending the open Internet, http://europa.eu/rapid/press-release_SPEECH-14-576_ en.htm (dostęp z 18.03.2015)

8. Diemidow O., Geopolityka cyberprzestrzeni - klasyczne koncepcje w nowym kontekście międzynarodowym, http://nowadebata.pl/2013/12/29/geopolityka-cyberprzestrzeni-klasyczne-koncepcje-w-nowym-kontekscie-miedzynarodowym/ (dostęp z 9.03.2015).

9. Digital Inclusion and Skills, http://ec.europa.eu/digital-agenda/en/news/scoreboard-2014-digital-inclusion-and-skills-eu-2014 (dostęp z 11.03.2015).

10. Doing the ICANN-can, http://www.economist.com/news/international/21599385-america-promises-release-its-grip-internets-phone-bookand-opens-up-debate (dostęp z 14.03.2014).

11. Encyklopedia PWN, hasło HTML, http://encyklopedia.pwn.pl/haslo/HTML;3912986.html (dostęp z 6.03.2015).

${ }^{63} \mathrm{~J}$. Kulesza, NETmundial... 
12. Encyklopedia PWN, hasło Internet, http://encyklopedia.pwn.pl/haslo/Internet;3915155.html (dostęp z 6.03.2015).

13. Encyklopedia PWN, hasło SGML http://encyklopedia.pwn.pl/haslo/SGML;3974442.html (dostęp z 6.03.2015).

14. Encyklopedia PWN,hasło WWW http://encyklopedia.pwn.pl/haslo/WWW;3998620.html (dostęp z 6.03.2015)

15. Hofmolk J., Internet jako nowe dobro wspólne, Warszawa 2009.

16. Introducing IANA, http://www.internetassignednumbersauthority.org/about (dostęp z 18.03.2015).

17. ITU releases 2014 ICT figures. Mobile-broadband penetration approaching 32 per cent. Three billion Internet users by end of this year, http://www.itu.int/net/pressoffice/press_releases/2014/23.aspx\#.VPmYK3yG9XE (dostęp z 6.02.2015).

18. Klimburg A., The Internet Yalta. Center for a new American Security, http://www.cnas.org/files/ documents/publications/CNAS_WCIT_commentary.pdf(dostęp z 9.03.2015).

19. Komunikat Komisji do Parlamentu Europejskiego, Rady, Europejskiego Komitetu Ekonomiczno-Społęcznego i Komitetu Regionów, Polityka wobec internetu i zarządzania internetem, Rola Europy w ksztaltowaniu przyszłości zarządzania internetem, COM(2014) 72 final, http://eur-lex.europa.eu/legal-content/PL/TXT/HTML/?uri=CELEX:52014DC0072\&from=EN (dostęp z 18.03.2015);

20. Kroes N., Stopping the Digital Cold War, Przemówienie z dnia 28 lutego 2013 r., http://europa. eu/rapid/press-release_SPEECH-13-167_en.htm (dostęp z 9.03.2015).

21. Kruger L. G., Internet Governance and the Domain Name System: Issues for Congress, http:// fas.org/sgp/crs/misc/R42351.pdf (dostęp z 12.03.2015).

22. Kulesza J., Międzynarodowe prawo internetu, Poznań 2007.

23. Kulesza J., NETmundial - mecz o przyszłość sieci, http://stosunki.pl/?q=content/netmundial-\%E2\%80\%93-mecz-o-przysz\%C5\%82o\%C5\%9B\%C4\%87-sieci (dostęp z 14.03.2015).

24. Kulesza J., Nowy rozdział międzynarodowego zarzadzania internetem - Affirmation of Commitments, „Ruch prawniczy, ekonomiczny i socjalny”, 2010, nr 3.

25. Kulesza J., Umiędzynarodowienie Siecia globalna - konieczność czy fikcja?, „Monitor Prawniczy" 2007, nr 3.

26. Kurbalija J., An Introduction to Internet Governance, Genewa 2014.

27. Kurbalija J., The EU on Internet governance: Strong on description - Weak on prescription, http://www.diplomacy.edu/blog/eu-internet-governance-strong-description- $\%$ E2\%80\%93-weak-prescription (dostęp z 6.03.2015).

28. Masters J., What is Internet Governance?, http://www.cfr.org/internet-policy/internet-governance/p32843 (dostęp z 6.03.2013).

29. Musiani F., Pohle J., NETmundial: only a landmark event if "Digital Cold War" rhetoric abandoned, „Internet Policy Review”, tom 3, 2014, nr 1, http://policyreview.info/articles/analysis/ netmundial-only-landmark-event-if-digital-cold-war-rhetoric-abandoned (dostęp z 12.03.2015).

30. NETmundial Multistakeholder Statement, http://netmundial.br/wp-content/uploads/2014/04/ NETmundial-Multistakeholder-Document.pdf (dostęp z 14.032015).

31. NETmundial, http://netmundial.br/about (dostęp z 14.03.2015).

32. NTIA Announces Intent to Transition Key Internet Domain Name Functions, http://www.ntia. doc.gov/press-release/2014/ntia-announces-intent-transition-key-internet-domain-name-functions (dostęp z 18.03.2015). 
33. Pettyjohn S. L., Net Gain. Washington Cedes Control of ICANN, http://www.foreignaffairs.com/ articles/141122/stacie-l-pettyjohn/net-gain (dostęp z 14.03.2015).

34. Proposal for a Council Decision establishing the European Union position for the review of the International Telecommunications Regulations to be taken at the World Conference on International Telecommunications or its preparatory process - Adoption, (ST-16217-2012-REV-1), http:// data.consilium.europa.eu/doc/document/ST-16217-2012-REV-1/en/pdf (dostęp z 18.03.2015).

35. Rada ds. Transportu, Telekomunikacji i Energii, Council conclusions on Internet Governance, 16200/14, http://data.consilium.europa.eu/doc/document/ST-16200-2014-INIT/en/pdf (dostęp z 18.03.2015).

36. Raport Komisji Nauki i Technologii dla Rozwoju (Commission for Science and Technology for Development - CSTD), The mapping of international Internet public policy issues, http:// unctad.org/meetings/en/SessionalDocuments/CSTD_2014_Mapping_Internet_en.pdf (dostęp z 12.03.2015).

37. Rezolucja Zgromadzenia Ogólnego ONZ 56/183, World Summit on the Information Society, http://www.itu.int/wsis/docs/background/resolutions/56_183_unga_2002.pdf (dostęp z 12.03.2015).

38. Rezolucja Zgromadzenia Ogólnego ONZ 68/302, Modalities for the overview by the General Assembly of the implementation of the outcomes of the World Summit on the Information Society, (A/RES/68/302), http://www.un.org/en/ga/search/view_doc.asp?symbol=A/RES/68/302 (dostęp z 17.03.2015).

39. Rogacin W., Wojna o kontrolę nad internetem: Rządy dąża do zalegalizowania kontroli państwa nad siecia, http://www.polskatimes.pl/artykul/714879, wojna-o-kontrole-nad-internetem-rzady-daza-do-zalegalizowania-kontroli-panstwa-nad-siecia,id,t.html? cookie $=1($ dostęp z 9.03.2015).

40. Signatories of the Final Acts: 89, http://www.itu.int/osg/wcit-12/highlights/signatories.html (dostęp z 18.03.2015).

41. Tunis Agenda For The Information Society, Document WSIS-05/TUNIS/DOC/6(Rev. 1)-E http://www.itu.int/wsis/docs2/tunis/off/6rev1.html (dostęp z 6.03.2015).

42. U.S. Principle on the Internet's Domain Name Adressing System http://www.ntia.doc.gov/files/ ntia/publications/usdnsprinciples_06302005.pdf (dostęp z 9.03.2015).

43. Vasagar J., Fontanella-Khan J., Angela Merkel backs EU internet to deter US spying, http://www. ft.com/intl/cms/s/0/dbf0081e-9704-11e3-809f-00144feab7de.html\#axzz3TtzWILun (dostęp z 9.03.2015).

44. Who We Are, http://www.internetsociety.org/who-we-are (dostęp z 18.03.2015).

45. Wyrok Trybunału Sprawiedliwości Unii Europejskiej z dnia 13 maja 2014 r. w sprawie C-131/12, Google Spain SL, Google Inc. przeciwko Agencia de Protección de Datos (AEPD), Mario Costeja González, http://curia.europa.eu/juris/liste.jsf?language=pl\&num=C-131/12 (dostęp z 11.03.2015).

\section{EUROPEAN UNION TOWARDS THE INTERNET GOVERNANCE PROCESS}

Abstract: In a relatively short time the Internet has become one of the main and the most important media of our times. The increasing number of users, as well as the growth of its role and importance in almost every aspect of social and economic life have led in recent years to the intensification of the discussion on the future of the Internet and the way it should be governed. From the very beginning the Internet developed bottom-up without a decision-making center responsible for its development. There are many organizations in the world operating at local, regional and 
global levels, that focus on different aspects of its operation and development. This process called "Internet governance" is the process within which governments, information and communication technology (ICT) companies and civil society work together to set standards, values, norms and decisions that shape the way we use the World Wide Web. This article attempts to explain this phenomenon, shows the origins of the dispute between the supporters of the multistakeholder model of the Internet governance. It also presents the proposals of some states to strengthen the role of governments in this process and presents the position of the European Union, which in this discussion may play a key role as a mediator in the debate about the future of the Internet governance.

Key words: Internet governance, European Union, ICANN, Internet, information society 